Cornell University Law School Scholarship@Cornell Law: A Digital Repository

Cornell Law Library Prize for Exemplary Student

Research Papers

Cornell Law Student Papers

$5-2017$

\title{
Columbia University and Incarcerated Worker Labor Unions Under the National Labor Relations Act
}

Kara Goad

Cornell Law School,klg227@cornell.edu

Follow this and additional works at: http://scholarship.law.cornell.edu/cllsrp

Part of the Labor and Employment Law Commons, and the Law Enforcement and Corrections Commons

\section{Recommended Citation}

Goad, Kara, "Columbia University and Incarcerated Worker Labor Unions Under the National Labor Relations Act" (2017). Cornell Law Library Prize for Exemplary Student Research Papers. 14.

http://scholarship.law.cornell.edu/cllsrp/14 


\section{Columbia University and Incarcerated Worker Labor Unions Under the National Labor \\ Relations Act}

\section{Introduction}

On September 9, 2016, an estimated 24,000 inmates in at least 29 prisons across the United States refused to work as part of a coordinated labor strike. ${ }^{1}$ Though the exact number of participants is difficult to confirm, a member of the committee that helped organize the strike states that this was the largest prison strike in U.S. history. ${ }^{2}$ An inmate in a South Carolina prison estimated that 350 of the 1,500 inmates there participated in the strike, refusing to appear for work assignments in an on-site, privately owned furniture factory and as the prison's landscapers, janitors, and cooks. ${ }^{3}$ A Michigan Department of Corrections spokesperson said that inmates at one Michigan facility did not report for kitchen work, forcing correctional officers to provide food. ${ }^{4}$ Four hundred inmates at that facility also marched peacefully in the yard before the prison went on lockdown. ${ }^{5}$ In Alabama, some corrections officers joined in the strike to protest overcrowded and understaffed prisons. ${ }^{6}$ The Incarcerated Workers Organizing

\footnotetext{
${ }^{1}$ Support Prisoner Resistance! Sept 9th 2016 Shakes History, IWW INCARCERATED WORKERS ORGANIZING COMMITTEE (Sept. 14, 2016), https://iwoc.noblogs.org/post/2016/09/14/supportprisoner-resistance-sept-9th-2016-shakes-history/.

${ }^{2}$ Alice Speri, The Largest Prison Strike in U.S. History Enters Its Second Week, THE INTERCEPT (Sept. 16, 2016), https://theintercept.com/2016/09/16/the-largest-prison-strike-in-u-s-historyenters-its-second-week/.

${ }^{3}$ E. Tammy Kim, A National Strike Against “Prison Slavery,” The New Yorker (Oct. 3, 2016), http://www.newyorker.com/news/news-desk/a-national-strike-against-prison-slavery.

${ }^{4}$ Kanyakrit Vongkiatkajorn, Why Prisoners Across the Country Have Gone on Strike, MotHER JONES (Sept. 19, 2016, 5:00 AM), http://www.motherjones.com/politics/2016/09/prison-strikeinmate-labor-work.

${ }^{5}$ Id.

${ }^{6}$ Beth Schwartzapfel, A Primer on the Nationwide Prisoners' Strike, The Marshall Project (Sept. 27, 2016, 10:00 PM), https://www.themarshallproject.org/2016/09/27/a-primer-on-thenationwide-prisoners-strike\#.odhyw56lJ.
} 
Committee ("IWOC"), part of the Industrial Workers of the World labor union, organized the strike through mailings and conference calls to inmates and their families and through partnerships with lawyers and activists. ${ }^{7}$ Through the strike, the inmates and organizers aimed to call attention to a range of grievances, including unfair pay for inmate work and inhumane prison conditions. $^{8}$

Casting light on and adding gravity to these issues is the IWOC's rallying call for the strike: "This is a Call to Action Against Slavery in America." 9 The IWOC is one of many voices in the growing discussion of prison labor as a form of modern-day slavery in the United States. ${ }^{10}$ Inmate labor at the Louisiana State Penitentiary, also known as Angola, provides a stark example of what gives rise to these discussions. Located on what was once a slave plantation, Angola is now home to a program under which inmates work in the same plantation fields for as little as two cents per hour. ${ }^{11}$ The prison can force the inmates to work after they are cleared by a doctor, and it is not required to compensate them. ${ }^{12}$ Section 1 of the Thirteenth Amendment authorizes this program when it provides that "[n]either slavery nor involuntary servitude, except as a punishment for crime whereof the party shall have been duly convicted, shall exist within the

\footnotetext{
${ }^{7}$ Kim, supra note 3 .

${ }^{8}$ See Schwartzapfel, supra note 6.

${ }^{9}$ Announcement of Nationally Coordinated Prisoner Workstoppage for Sept 9, 2016, IWW INCARCERATED WORKERS ORGANIZING COMMITTEE (Apr. 1, 2016), https://iwoc.noblogs.org/post/2016/04/01/announcement-of-nationally-coordinated-prisonerworkstoppage-for-sept-9-2016/.

10 See Whitney Benns, American Slavery, Reinvented, THE ATLANTIC (Sept. 21, 2015), http://www.theatlantic.com/business/archive/2015/09/prison-labor-in-america/406177/; Carimah Townes, 'It's Just Dressed Up Slavery': America's Shadow Workforce Rises Up Against Prison Labor, THINKPROGRESS (Sept. 9, 2016), https://thinkprogress.org/its-just-dressed-up-slaveryamerica-s-shadow-workforce-rises-up-against-prison-labor-e8ee1b5a8738\#.1q61uxtp1; Nicky Woolf, Inside America's Biggest Prison Strike: 'The $13^{\text {th }}$ Amendment Didn't End Slavery, THE GUARDIAN (Oct. 22, 2010), https://www.theguardian.com/us-news/2016/oct/22/inside-us-prisonstrike-labor-protest; $13^{\mathrm{TH}}$ (Kandoo Films 2016).

${ }^{11}$ Benns, supra note 10 .

${ }^{12} I d$.
} 
United States.” ${ }^{13}$ Programs like those at Angola also exist because legislatures and courts have prevented traditional labor and employment law rights and protections from applying to incarcerated workers. $^{14}$

This Note seeks to demonstrate that labor law can provide one avenue for remedying some of the grievances of incarcerated workers. ${ }^{15}$ In particular, this Note argues that the National Labor Relations Board’s (“NLRB” or “the Board”) August 2016 decision regarding the right of graduate research assistants to unionize in Columbia University creates a particularly relevant opening for arguing that incarcerated workers are also able to unionize under the National Labor Relations Act (“NLRA” or "the Act”). Part I of this Note provides background information on the prison system in the United States and the ways in which inmate labor occurs within it, as well as on the NLRA and the NLRB. Part II lays the groundwork for the application of Columbia University to the situation of incarcerated workers by providing an overview of decisions regarding the status of incarcerated workers under labor and employment statutes before Columbia University and of the Board's decision in Columbia University. Part III contrasts the Board's reasoning in Columbia University with these earlier decisions and argues that the Board has set itself up to disagree with their reasoning and in fact has interpreted the Act such that incarcerated workers should be protected under it. Part III also raises and addresses a number of potential obstacles to incarcerated worker unionization and contends that none of these obstacles must necessarily prevent their unionization. Though Part III also reveals that the

\footnotetext{
${ }^{13}$ U.S. CONST. amend. XIII; id.

${ }^{14}$ See Eric M. Fink, Union Organizing \& Collective Bargaining for Incarcerated Workers, 52 IDAHO L. REV. 953, 955 (2016).

15 The proposals in this Note are proposals for changes that will occur within the United States' existing incarceration system. However, they could also operate as part of movements that call for the abolition of this system itself. See Angela Y. DAVIS, ARE Prisons OBsolete? 103-04 (2003).
} 
number of incarcerated workers who would currently fall under the Act's protection is somewhat limited, this Note argues that in light of the ways in which prison labor is a form of modern-day slavery, the Board, courts, and the public should seize this opportunity to establish a foundation for incarcerated worker unionization. ${ }^{16}$

\section{Background}

\section{A. The U.S. Prison System}

The structure of the prison system in the United States, and how inmate labor occurs within it, will affect the application of the NLRB's decision in Columbia University to incarcerated worker unionization, as discussed in greater detail in Part III. In the United States, federal prisons hold individuals charged or convicted with federal crimes. ${ }^{17}$ Each state also has its own prison system, and municipalities and counties typically operate the country’s jails. ${ }^{18}$ In 2014, federal prisons held 210,567 individuals, and state prisons held 1,350,958 individuals. ${ }^{19}$ Local jails held an additional 744,600 individuals. ${ }^{20}$

At both the federal and state level, prisons are operated by either the government or private corporations. ${ }^{21}$ In 2014, government-operated (or “public”) federal prisons held 169,500 individuals, and privately-operated federal prisons and community correction centers ${ }^{22}$ held

${ }^{16}$ For another argument in favor of supporting incarcerated worker unionization even on a relatively small scale, see Fink, supra note 14, at 956.

${ }^{17}$ BUREAU OF INT'L NARCOTICS \& LAW ENF'T AFFAIRS ET AL., U.S. DEP'T OF STATE, A Practical Guide to Understanding and Evaluating Prison Systems 8 (2012).

${ }^{18} I d$. at 9.

${ }^{19}$ E. Ann Carson, Bureau of Justice Statistics, Prisoners Under the Jurisdiction of State or Federal Correctional Authorities, DeCEMBer 31, 1978-2014 (2015).

${ }^{20}$ Danielle Kaeble, et al., Bureau of Justice Statistics, Correctional Populations in THE UNITED STATES, 20142 (2016).

21 See id. at 22.

22 More commonly known as "halfway houses," these centers are operated by private companies under contracts with the Federal Bureau of Prisons. Memorandum from Sally Q. Yates to the Acting Director of the Federal Bureau of Prisons 1 n.1 (Aug. 18, 2016) [hereinafter Yates Memorandum]. 
40,000 individuals. ${ }^{23}$ At the state level, government-operated state prisons held 1,172,600 individuals, and privately-operated state prisons held 91,200 individuals in $2014 .{ }^{24}$ In the United States, the two largest private prison corporations are CoreCivic (formerly known as Corrections Corporation of America) and The GEO Group. ${ }^{25}$ These corporations design, construct, expand, and manage the prisons they operate. ${ }^{26}$ Both CoreCivic and The GEO Group operate prisons under contracts with the federal government and with state governments. ${ }^{27}$

On August 18, 2016, then-U.S. Deputy Attorney General Sally Q. Yates sent a memo to the Federal Bureau of Prisons directing the Bureau to either decline to renew or substantially reduce the scope of its contracts with private prison corporations as the contracts expired. ${ }^{28}$ This move by the federal government away from contracting with private prison corporations was a result of reports showing that private prisons do not provide the same level of correctional services, programs, resources, safety, or security that public prisons provide. ${ }^{29}$ However, on February 23, 2017, Attorney General Jeff Sessions issued a memorandum reversing the Obama-

${ }^{23}$ KAEBLE, supra note 20, at 22.

${ }^{24}$ Id.

${ }^{25}$ Chico Harlan, “The Private Prison Industry Was Crashing - Until Donald Trump’s Victory,” WASH. POST: WONKBLOG (Nov. 10, 2016), https://www.washingtonpost.com/news/wonk/wp/2016/11/10/the-private-prison-industry-wascrashing-until-donald-trumps-victory/?utm_term=.de35a7a79888.

${ }^{26}$ See Who We Are, CCA, http://www.cca.com/who-we-are (last visited Jan. 27, 2017).

${ }^{27}$ Management \& Operations, THE GEO GROUP, INC., http://www.geogroup.com/Management_and_Operations (last visited Jan. 18, 2017); See CCA's Nationwide System of Correctional Centers, CCA, http://www.cca.com/locations (last visited Jan. 18, 2017).

${ }^{28}$ Yates Memorandum, supra note 22, at 2.

${ }^{29} \mathrm{Id}$. at 1-2. 
era policy. ${ }^{30}$ In the memo, Attorney General Sessions directed the Bureau to return to its previous, unrestricted approach to contracting with private prisons. ${ }^{31}$

\section{B. Prison Labor in the United States}

The latest census of federal and state prisons reports that in 2005, $88 \%$ of these facilities offered inmate work programs. ${ }^{32}$ More than half (54\%) of the inmates at facilities offering work programs had work assignments. ${ }^{33}$ At the time of the census, a much higher percentage of public facilities (97\%) offered work assignments to inmates than did private facilities (56\%). ${ }^{34}$ The distinction between federal and state facility offerings was less drastic — work assignments were available to inmates in $98 \%$ of federal facilities and $87 \%$ of state facilities. ${ }^{35}$ A 2014 article provides more recent figures and estimates that 870,000 inmates worked full time in $2014 .^{36}$ Inmates in public federal prisons are required to work if they are medically able, ${ }^{37}$ and the same is also true for some public state prisons. ${ }^{38}$

Prison work programs consist of different jobs and come in different organizational systems. In the most common "state account” system, the government department that operates

30 See Matt Zapotosky, Justice Department Will Again Use Private Prisons, WAsH. Post (Feb. 23, 2017), https://www.washingtonpost.com/world/national-security/justice-department-willagain-use-private-prisons/2017/02/23/da395d02-fa0e-11e6-be051a3817ac21a5_story.html?utm_term=.691e37802931.

${ }^{31}$ See id.

32 James J. Stephan, Bureau of Justice Statistics, Census of State And Federal CORRECTIONAL FACILITIES, 20055 (2008).

${ }^{33} \mathrm{Id}$.

${ }^{34} \mathrm{Id}$.

${ }^{35} I d$.

${ }^{36}$ Beth Schwartzapfel, Modern-Day Slavery in America's Prison Workforce, THE AMERICAN PROSPECT, May 28, 2014, http://prospect.org/article/great-american-chain-gang.

${ }^{37}$ Work Programs, FED. BUREAU OF PRISONS, https://www.bop.gov/inmates/custody_and_care/work_programs.jsp (last visited Jan. 15, 2017).

${ }^{38}$ See, e.g., N.C. GEN. STAT. § 148-26. 
the prison wholly manages the work program, sells the product, and receives the revenue. ${ }^{39}$ In the case of public federal prisons, this system takes the form of the wholly owned government corporation, Federal Prison Industries, Inc., also known as UNICOR. ${ }^{40}$ UNICOR operates 110 factories at 79 federal prisons. ${ }^{41}$ UNICOR's incarcerated workers take calls at call centers, repair vehicles, and make furniture, among many other things. ${ }^{42}$ These workers receive approximately $\$ 0.04$ of each $\$ 1.00$ in UNICOR sales revenue. ${ }^{43}$ Every state also has its own UNICOR-like prison industry program, ${ }^{44}$ though incarcerated workers in some of these programs do not receive any payment. ${ }^{45}$

Under a "contract" system, a private firm, rather than the government, operates the work program pursuant to a contract with the prison. ${ }^{46}$ Workers in this type of system remain in the prison's custody while they work. ${ }^{47}$ Work release programs, in which inmates are permitted to work for pay in the community during the day, ${ }^{48}$ also fall under the umbrella of contract systems.

${ }^{39}$ See Noah D. Zatz, Working at the Boundaries of Markets: Prison Labor and the Economic Dimension of Employment Relationships, 61 VAND. L. REV. 857, 869-70 (2008).

${ }^{40}$ See Program Details, Fed. BuREAu OF PRISONS, https://www.bop.gov/inmates/custody_and_care/unicor_about.jsp (last visited Jan. 15, 2017). ${ }^{41}$ Caitlin Seandel, Prison Labor: Three Strikes and You're Hired, ELLA BAKER CTR. FOR HUMAN RighTS: ElLA's VoICE (June 27, 2013), http://ellabakercenter.org/blog/2013/06/prison-labor-isthe-new-slave-labor.

${ }^{42}$ See UNICOR Schedule of Products and Services, UNICOR, https://www.unicor.gov/SOPalphalist.aspx (last visited Jan. 15, 2017).

${ }^{43}$ Program Details, supra note 40.

${ }^{44}$ Sarah Shemkus, Beyond Cheap Labor: Can Prison Work Programs Benefit Inmates?, THE GUARDIAN, Dec. 9, 2015, https://www.theguardian.com/sustainablebusiness/2015/dec/09/prison-work-program-ohsa-whole-foodsp-inmate-labor-incarceration; see, e.g., About CALPIA, STATE OF CAL. PRISON INDUS. AUTH., http://www.calpia.ca.gov/About_PIA/AboutPIA.aspx (last visited Jan. 15, 2017).

${ }^{45}$ See Patrice A. Fulcher, Emancipate the FLSA: Transform the Harsh Economic Reality of Working Inmates, 27 J. Civ. RTs. \& ECON. Dev. 679, 694 (2015) (noting that the Georgia Department of Corrections does not pay incarcerated workers).

${ }^{46}$ See Zatz, supra note 39, at 870.

${ }^{47}$ See Fink, supra note 14, at 958.

${ }^{48}$ See Minn. Dep’t of Corr., Work Release Program 1 (2012), http://www.doc.state.mn.us/pages/files/6313/6586/2224/WorkRelease.pdf. 
Though the federal government does not use a contract labor system in any of its prisons, public state prisons have work programs operating under this system. According to a 1995 Department of Justice report, Escod Industries, a private corporation, operates a manufacturing plant at Evans Correctional Facility, a public South Carolina prison. ${ }^{49}$ Incarcerated workers there assemble electronic cables that Escod has sold to companies like IBM. ${ }^{50}$ At Perry Correctional Institute, another public South Carolina prison, incarcerated workers assemble wooden furniture for an onsite private company. ${ }^{51}$

Though it is not clear from the limited information that CoreCivic and The GEO Group provide, these private prison corporations could operate their work programs under either a state account-like system or a contract system. CoreCivic states that work assignments for its inmates can include building or manufacturing goods. ${ }^{52}$ The GEO Group notes only that it offers vocational programming that includes on-the-job training and partnerships with local employers. ${ }^{53}$ Though neither corporation provides information on incarcerated worker salaries, one source estimates that they receive as little as $\$ 0.17$ per hour for a maximum of six hours per day, which totals $\$ 20.00$ per month. ${ }^{54}$ At the highest-paying private prison in Tennessee, run by CoreCivic, the same source reports that incarcerated workers receive $\$ 0.50$ per hour for highlyskilled positions. ${ }^{55}$

\footnotetext{
49 George E. SeXton, U.S. DeP’t OF Justice, Work in AmericA’s Prisons: Joint Ventures WITH THE PRIVATE SECTOR 5 (1995).

${ }^{50} I d$.

${ }^{51} \mathrm{Kim}$, supra note 3.

52 Work Assignments, CCA, http://www.cca.com/inmate-services/inmate-reentrypreparation/work-assignments (last visited Jan. 18, 2017).

${ }^{53}$ In-Custody Programs, THE GEO GROUP, INC., http://www.geogroup.com/InCustody_Evidtence_Based_Programs (last visited Jan 18, 2017).

${ }^{54}$ Vicky Peláez, The Prison Industry in the United States: New Form of Slavery?, GLOBAL RESEARCH, Aug. 28, 2016, http://www.globalresearch.ca/the-prison-industry-in-the-unitedstates-big-business-or-a-new-form-of-slavery/8289. ${ }^{55}$ Id.
} 
In addition to working under these two systems, it is common for incarcerated workers to contribute to the prison's day-to-day operations. ${ }^{56}$ In public federal prisons, inmates work in food service and as orderlies, plumbers, painters, and groundskeepers. ${ }^{57}$ These workers receive $\$ 0.12$ to $\$ 0.40$ per hour. ${ }^{58}$ Public state prisons also use incarcerated workers to maintain day-today facility operations and maintenance. ${ }^{59}$ Additionally, CoreCivic states that its incarcerated workers serve as custodial assistants or food service attendants. ${ }^{60}$

Since the early 1900s, when labor unions and small businesses concerned with unfair competition from goods produced by incarcerated workers put pressure on the federal government, Congress has restricted the sale of these goods in interstate commerce. ${ }^{61}$ In 1935, Congress passed the Ashurst-Sumners Act, which made it a federal crime to knowingly transport prison-made goods into a state that prohibited their sale. ${ }^{62}$ Congress then amended the AshurstSumners Act in 1940 to make the interstate transportation and sale of prison-made goods a federal crime regardless of state laws. ${ }^{63}$ However, this restriction does not apply to goods manufactured for use by the federal government, the District of Columbia, state governments, or political subdivisions of a state or non-profit organization. ${ }^{64}$ As a result of the Ashurst-Sumners

\footnotetext{
${ }^{56}$ See Zatz, supra note 39 , at 870.

${ }^{57}$ Work Programs, supra note 37.

${ }^{58} \mathrm{Id}$.

${ }^{59}$ See, e.g., Hawait Dep’t of Pub. SAFety, Policy No. Corr. 14.02, InMate Work PROGRAM/COMPENSATION (2010).

${ }^{60}$ Work Assignments, supra note 52.

${ }^{61}$ See Fink, supra note 14, at 958.

${ }^{62}$ Fulcher, supra note 45, at 689.

${ }^{63} \mathrm{Id}$.

${ }^{64}$ See 18 U.S.C.A. § 1761(b).
} 
Act and its exceptions, UNICOR sell its products only to the federal government, ${ }^{65}$ and state prison industry programs sell only to state and local governments. ${ }^{66}$

Congress created an additional exception to the Ashurst-Sumners Act when it created the Prison Industry Enhancement Certification Program (“PIE”) in 1979. ${ }^{67}$ The program exempts certified state and local departments of corrections from the Ashurst-Sumners Act's restrictions, permitting them to sell goods produced by incarcerated workers in the open market. ${ }^{68}$ To become certified under the program, the state or local department of corrections must demonstrate that it meets the requirements set out in the Mandatory Criteria for Program Participation. ${ }^{69}$ As of September 30, 2016, 47 jurisdictions were PIE-certified, and a total of 5,435 inmates worked in programs in these jurisdictions. ${ }^{70}$ These programs involve partnerships with private corporations, and these corporations either serve as customers of the departments of correction or as direct employers of incarcerated workers. ${ }^{71}$ PIE-certified programs must pay wages "at a rate not less than that paid for work of a similar nature in the locality in which the work is performed." ${ }^{72}$ However, corrections departments are free to take deductions from the wages of incarcerated workers for taxes, room and board, family support, and victims’

\footnotetext{
${ }^{65}$ Customers and Private Sector FAQs, UNICOR, https://www.unicor.gov/FAQ_Market_Share.aspx\#1 (last visited Jan. 28, 2017).

${ }^{66}$ See Fink, supra note 14, at 958.

67 See Domingo S. Herraiz, U.S. DeP’t of Justice, OfFice of Justice Programs, Prison INDUSTRY ENHANCEMENT CERTIFICATION PROGRAM 1 (2004).

68 See id.

${ }^{69} I d$. See id. at 3 for these requirements.

${ }^{70}$ Bureau of Justice Assistance, Prison Industry EnHANCEMENT CERTIFICATION Program CertificAtion \& Cost ACCOUnTing CEnTER Listing, STATISTICS FOR THE QUARTER ENDing SEPTEMBER 30, 20161 (2016), available at http://www.nationalcia.org/wpcontent/uploads/Third-Quarter-2016-Certification-Listing-Report.pdf.

${ }^{71}$ See id. at 3-4 (listing private corporations as participating in projects under either a “customer” or "employer” model).

${ }^{72}$ Id. at 3.
} 
compensation, and these deductions can total up to $80 \%$ of a worker's gross wages. ${ }^{73}$ For the quarter ending September 30, 2016, PIE-certified programs resulted in gross wages of $\$ 11,104,906$, but after deductions, net wages to incarcerated workers were only $\$ 4,780,857 .^{74}$ Thus, each incarcerated worker in a PIE-certified program made approximately $\$ 98.00$ each month in 2016.

\section{The National Labor Relations Act and the National Labor Relations Board}

Congress passed the National Labor Relations Act in 1935 to eliminate obstructions to the free flow of commerce, including industrial strife and unequal bargaining power between employers and employees, by “encouraging the practice and procedure of collective bargaining and by protecting the exercise by workers of full freedom of association, self-organization, and designation of representatives of their own choosing, for the purpose of negotiating the terms and conditions of their employment or other mutual aid or protection.”75 To achieve this end, the Act forbids employers from interfering with, restraining, or discharging individuals engaged in protected activities, which include self-organization, collective bargaining, and engaging in other concerted activities for the purpose of collective bargaining or other mutual aid or protection. ${ }^{76}$ These protections only apply to individuals who fall within the statute's definition of

\footnotetext{
${ }^{73} \mathrm{Id}$.

${ }^{74}$ Bureau of Justice Assistance, Prison Industry EnHANCEMENT CERTIFICATION Program QuARTERly REPORT, STATISTICS FOR THE QuARTER ENDING SEPTEMBER 30, 20163 (2016), available at http://www.nationalcia.org/wp-content/uploads/Third-Quarter-2016-Statistical-DataReport.pdf.

7529 U.S.C. § 151.

${ }^{76}$ See 29 U.S.C. §§ 157-58.
} 
employee.”77 Further, they only apply to employees who work for employers that are covered by the Act, a category that excludes the federal and state governments. ${ }^{78}$

The NLRA also establishes the National Labor Relations Board, which consists of five members that are appointed by the President for five-year terms. ${ }^{79}$ The Board primarily acts as a quasi-judicial body, ${ }^{80}$ deciding cases regarding unfair labor practices under the Act. ${ }^{81}$ However, the Board also oversees the union election process, which occurs when employees submit a petition to the Board to certify or decertify a union as their bargaining representative. ${ }^{82}$ Additionally, the Board fills gaps in the NLRA by engaging in rulemaking or by announcing policies and rules in the matters it adjudicates. ${ }^{83}$ The Board relies almost exclusively on adjudication, rather than rulemaking, to establish rules and policies. ${ }^{84}$ Notably, the doctrine of stare decisis, which refers to courts' practice of adhering to a previous decision when that

77 See 29 U.S.C. $§ 157$ (“Employees shall have the right to self-organization, to form, join, or assist labor organizations ....” (emphasis added)). The statute defines "employee” as "any employee . . . but shall not include any individual employed as an agricultural laborer, or in the domestic service of any family or person at his home, or any individual employed by his parent or spouse, or any individual having the status of an independent contractor, or any individual employed as a supervisor, or any individual employed by an employer subject to the Railway Labor Act . . . or by any other person who is not an employer as herein defined.” 29 U.S.C. $\S$ 152(3).

78 See 29 U.S.C. $§ 152(2)$ (defining “employer” as “any person acting as an agent of an employer, directly or indirectly, but shall not include . . . any State or political subdivision thereof").

7929 U.S.C. \& 153(a).

80 The Board, NATIONAL LABOR RELATIONS BOARD, https://www.nlrb.gov/who-we-are/board (last visited March 4, 2017).

${ }^{81}$ See Decide Cases, NATIONAL LABOR RELATIONS BOARD, https://www.nlrb.gov/what-wedo/decide-cases (last visited March 4, 2017).

${ }^{82}$ See Conduct Elections, NATIONAL LABOR RELATIONS BOARD, https:/www.nlrb.gov/what-wedo/conduct-elections (last visited March 5, 2017).

83 See Tanja L. Thompson \& R. Bradley Mokros, As the Pendulum Swings: The Role of PRECEDENT In NATIONAL LABOR RELATIONS BoARD DECISIONS 1 (2009).

${ }^{84}$ See Charlotte Garden, Toward Politically Stable NLRB Lawmaking: Rulemaking vs. Adjudication, 64 EMORY L.J. 1470, 1471 (2015). 
decision addresses the issue before the court, ${ }^{85}$ does not strictly apply to the Board's adjudicatory process. ${ }^{86}$ However, circuit courts have held that "the Board may not depart . . . from its usual rules of decision to reach a different, unexplained result in a single case." ${ }^{87}$ In addition, the Board does refer to its prior decisions as "precedent," ${ }^{88}$ and it considers the facts and reasoning of these decisions when it addresses similar situations. ${ }^{89}$

\section{Incarcerated Workers Then, Columbia University Now}

\section{A. Incarcerated Workers as Employees before Columbia University}

Neither the NLRB nor a federal court has specifically considered whether incarcerated workers are employees under the NLRA. ${ }^{90}$ However, federal courts have addressed whether incarcerated workers in work release programs were properly included in a collective bargaining unit with other employees under the NLRA. ${ }^{91}$ These courts found that incarcerated workers on work release could be included in bargaining units alongside non-incarcerated employees under

\footnotetext{
85 See Stare Decisis, Black's LAW DictionaRy (10th ed. 2014).

${ }^{86}$ See ThOMPSON \& MoKros, supra note 83, at 1 (citing NLRB v. Kostel Corp., 440 F.2d 347, 350 (7th Cir. 1971) ("The doctrine of stare decisis does not require that the Board's policies and standards be unchangeable since it must meet changing conditions by corresponding changes in policies and standards.”))

${ }^{87}$ NLRB v. Int'l Union of Operating Engineers, Local 925, 460 F.2d 589, 604 (5th Cir. 1972) (citing Mary Carter Paint Co. v. FTC, 333 F.2d 654 (1964)).

88 See Boston Medical Center Corp., 330 N.L.R.B. 152, 152 (1999) (“The Petitioner, mindful of the Cedars-Sinai and St. Clare's Hospital precedent, requests that the Board overrule that precedent.”).

${ }^{89}$ See id. at 159.

${ }^{90}$ See Fink, supra note 14 at 966.

${ }^{91}$ See Speedtrack Prods. Grp., Ltd. v. N.L.R.B., 114 F.3d 1276, 1278-82 (D.C. Cir. 1997); Rosslyn Concrete Constr. Co. v. N.L.R.B., 713 F.2d 61, 63-64 (4th Cir. 1983).
} 
the Act. ${ }^{92}$ These holdings would be consistent with including incarcerated workers in general as employees under the NLRA. ${ }^{93}$

Federal courts have also addressed whether incarcerated workers are employees under two other federal labor and employment statutes — the Fair Labor Standards Act ("FLSA") and Title VII of the Civil Rights Act of 1964 ("Title VII"). ${ }^{94}$ The definition of "employee" in these two statutes is very similar to that in the NLRA; ${ }^{95}$ thus, looking to judicial opinions regarding whether incarcerated workers meet the definition of "employee" under FLSA and Title VII is useful for considering their status as employees under the NLRA.

In his article on the economic dimensions of employment relationships, Noah D. Zatz categorizes the ways in which courts have evaluated whether incarcerated workers are protected under FLSA and Title VII. ${ }^{96}$ The vast majority of these courts have concluded that incarcerated worker claims for protection under these statutes fail. ${ }^{97}$ Zatz explains that this conclusion is a result of courts adopting an "exclusive market” approach to determining what constitutes employment. ${ }^{98}$ Under this approach, courts find that incarcerated workers and the institutions

\footnotetext{
${ }^{92}$ See Rosslyn Concrete, 713 F.2d at 64; cf. Speedtrack Prods., 114 F.3d at 1282 (holding that the NLRB's decision that the work release inmates did not share a community of interest with other unit employees and thus could not be part of the bargaining unit was unreasonable).

${ }^{93}$ See Fink, supra note 14, at 996.

${ }^{94}$ See Zatz, supra note 39, at n.101-02 (collecting cases).

${ }^{95}$ FLSA defines an employee as "any individual employed by an employer." 29 U.S.C. § 203(e)(1). Title VII also defines an employee as "an individual employed by an employer." 42 U.S.C § 2000e(f). The NLRA states that “[t]he term 'employee’ shall include any employee." 29 U.S.C. § 152(3).

${ }^{96}$ See id.at 884-896.

${ }^{97}$ Compare id. at n.101-02 (collecting over forty-five cases in which courts found no employment relationship), with id. at n.103 (collecting seven cases in which courts found that there could be an employment relationship at the motion to dismiss or summary judgment stage). ${ }^{98}$ See id. at 882.
} 
for which they work are in nonmarket or noneconomic relationships, and thus they are not employees and employers in an employment relationship. ${ }^{99}$

Many of these courts find that the relationship between incarcerated workers and the institutions for which they work is nonmarket or noneconomic by conflating economic relationships with contract relationships. ${ }^{100}$ As Zatz explains, this type of reasoning has three components- there is no free contract when prison labor is involuntary, there is no contract when there is no exchange between the parties, and whatever exchange exists between the parties fails to take the form of a discrete bargain. ${ }^{101}$ The Ninth Circuit's reasoning in Morgan $v$.

MacDonald illustrates the first two of these components. There, the court states:

Under Nev. Rev. Stat. § 209.461, all inmates are required to work or receive training for 40 hours each week. Thus, Morgan was in no sense free to bargain with would-be employers for the sale of his labor; his work at the prison was merely an incident of his incarceration. Morgan and the prison didn't contract with one another for mutual economic gain, as would be the case in a true employment relationship; their affiliation was "penological, not pecuniary.” Because the economic reality of Morgan's work at the prison clearly indicates that his labor "belonged to the institution," he cannot be deemed an employee under the FLSA. ${ }^{102}$

The Fourth Circuit illustrates the third component when it notes in Harker v. State Use Industries that the parties "do not deal at arms’ length." ${ }^{103}$ Thus, as Zatz explains, they do not encounter each other as strangers who engage in a discreet bargain. ${ }^{104}$ Key to both of these decisions is that the reasoning of the courts leads to the conclusion that the relationship between incarcerated

\footnotetext{
${ }^{99}$ See id.

${ }^{100}$ See id. at 885; see also Vanskike v. Peters, 974 F.2d 806, 810 (7th Cir. 1994) (stating that "[p]risoners are essentially taken out of the national economy upon incarceration. When they are assigned work within the prison for purposes of training and rehabilitation, they have not contracted with the government to become its employees”).

101 See Zatz, supra note 39, at 885.

10241 F.3d 1291, 1293 (9th Cir. 1994) (citations omitted).

103990 F.2d 131, 133 (4th Cir. 1993).

${ }^{104}$ See Zatz, supra note 39, at 891-92.
} 
workers and the institution for which they work is a noneconomic relationship. Then, under the exclusive market approach, they are also not in an employment relationship.

Other courts do not focus on whether the relationship is a market or economic one before finding that an incarcerated worker is not an employee under FLSA or Title VII. Instead, they focus on the presence of other relationships between the two parties and find that these other relationships preclude the existence of an employment one. For example, in Williams v. Meese, the Tenth Circuit held that an incarcerated worker was not an employee under Title VII or the Age Discrimination in Employment Act because:

[Plaintiff's] relationship with the Bureau of Prisons, and therefore, with the defendants, arises out of his status as an inmate, not an employee. Although his relationship with defendants may contain some elements commonly present in an employment relationship, it arises "from [plaintiff's] having been convicted and sentenced to imprisonment in the [defendants'] correctional institution. The primary purpose of their association [is] incarceration, not employment." 105

If the NLRB were to use this reasoning or reasoning based in contract theory to evaluate incarcerated worker claims for protection under the NLRA, these claims would fail because both lines of reasoning lead to the conclusion that incarcerated workers are not statutory employees.

\section{B. The NLRB's Decision in Columbia University}

In its August 2016 Columbia University decision, the NLRB found that student teaching assistants are employees under the NLRA. ${ }^{106}$ In doing so, it overturned Brown University, a 2004 Board decision holding that student teaching assistants were not employees under the NLRA because they "are primarily students and have a primarily educational, not economic,

\footnotetext{
105926 F.2d 994, 997 (10th Cir. 1991) (quoting Prisoner Not Protected From Racial Job Bias, 2 Empl. Proc. Guide (CCH) I 6865, at 7009 (Apr. 18, 1986)).

106 See N.L.R.B. Case No. 02-RC-143012 at *1.
} 
relationship with their university.”107 The Columbia University Board said regarding this reasoning:

The fundamental error of the Brown University Board was to frame the issue of statutory coverage not in terms of the existence of an employment relationship, but rather on whether some other relationship between the employee and the employer is the primary one-a standard neither derived from the statutory text of Section 2(3) nor from the fundamental policy of the Act. ${ }^{108}$

According to this decision, as long as there is an employment relationship, the existence of some other relationship not covered by the Act does not prevent an individual from being protected as an employee. ${ }^{109}$ Further, the Columbia University Board notes:

The Board and the courts have repeatedly made clear that the extent of any required "economic" dimension to an employment relationship is the payment of tangible compensation. Even when such an economic component may seem comparatively slight, relative to other aspects of the relationship between worker and employer, the payment of compensation, in conjunction with the employer's control, suffices to establish an employment relationship for purposes of the Act. ${ }^{110}$

The Board then explains that multiple relationships between employers and employees can coexist because the Act permits the Board to define the scope of the mandatory bargaining over wages, hours, and other terms and conditions of employment that will occur between employers and employees. ${ }^{111}$ Thus, because employees and employers must bargain only about subjects related to their employment relationship, this bargaining need not implicate their other relationships.

\footnotetext{
${ }^{107} \mathrm{Id}$.

${ }^{108} \mathrm{Id}$. at 5 .

${ }^{109}$ See id. at 1.

${ }^{110} \mathrm{Id}$. at 5.

${ }^{111}$ See id. at 6.
} 
The Columbia University decision builds upon similar reasoning by the Board in Boston Medical Center Corp. In that decision, the Board overruled an earlier finding that interns and residents in hospitals were not employees under the NLRA because they were primarily serving as students rather than employees. ${ }^{112}$ The Boston Medical Center Corp. Board said of that reasoning, "residents and fellows fall within the broad definition of 'employee' under Section 2(3), notwithstanding that a purpose of their being at a hospital may also be, in part, educational." 113

\section{Incarcerated Workers as Employees Under the NLRA After Columbia University: Application and Obstacles}

\section{A. Applying Columbia University}

The Board's language in Boston Medical Center and Columbia University contrasts markedly with the earlier reasoning regarding incarcerated workers under labor and employment statutes described in Part II of this Note. Both Board decisions emphasize that the relationship between an employee and an employer need not be primarily one of employment. Indeed, the Columbia University Board declares that it is a fundamental error to adopt this approach when determining statutory coverage. ${ }^{114}$ Instead, the Board emphasizes that the focus should be on whether an employment relationship exists, regardless of whether it exists alongside other relationships. This approach forecloses the line of reasoning that the court took in Williams $v$. Meese to find that incarcerated workers were not employees. Further, the Board notes that it has “repeatedly made clear” that the only economic dimension necessary for an employment relationship is the payment of tangible compensation and that an employment relationship

\footnotetext{
112 See Boston Medical Center Corp., supra note 88, at 152.

${ }^{113} \mathrm{Id}$. at 160.a

${ }^{114}$ N.L.R.B. Case No. 02-RC-143012 at *5.
} 
requires only this payment and employer control over the employee. ${ }^{115}$ This minimal requirement for the economic component of employment relationships does away with the extensive work that courts have done to find that incarcerated workers are in noneconomic relationships with their employer institutions because the relationships lack aspects of contract ones.

This comparison shows that the Board has set itself up to disagree with the reasoning described in Part II that finds that incarcerated workers are not in employment relationships with the institutions in which they work. Moreover, the Board's established approach to determining if an employment relationship is present-looking to the presence of employer control and payment of compensation-accommodates the situations of many incarcerated workers. As described in Part I, incarcerated workers are often paid for their labor, though the amount of pay is generally very small. Further, courts have acknowledged that the relationship between these workers and their employers meets a control test. ${ }^{116}$ Taken together, this suggests that the Board has created an opening for finding that incarcerated workers are employees under the NLRA. ${ }^{117}$

However, such a finding would not guarantee a clear path to unionizing for incarcerated workers. The remainder of this Part discusses additional obstacles that will likely arise on this path and argues that none of these obstacles must necessarily prevent incarcerated worker unionization. Further, it argues that the Board and courts should make a strong effort to

\footnotetext{
115 Id.

116 See Vanskike v. Peters, 974 F.2d 806, 810 (7th Cir. 1994) (stating that "there is obviously enough control over the prisoner"); Zatz, supra note 39, at 872 ("Since the 1980s, however, courts have accepted that prison labor usually satisfies the relevant tests for control.”); $c f$. Carter v. Dutchess Cmty. College, 735 F.2d 8, 15 (2d Cir. 1984) (holding that the plaintiff's claim should not be dismissed on summary judgment because there was sufficient evidence of control). ${ }^{117}$ Notably, the General Counsel of the NLRB has already begun applying the reasoning in Columbia University outside the context of graduate teaching assistants. See infra note 123.
} 
overcome these obstacles in light of the ways that incarcerated worker labor is a form of modernday slavery.

\section{B. The Board's Statutory and Discretionary Jurisdiction}

Because Congress passed the NLRA pursuant to its authority under the Commerce Clause, ${ }^{118}$ the NLRB's statutory jurisdiction over a case depends on an employer's activity in interstate commerce. ${ }^{119}$ The Board has established standards for asserting this statutory jurisdiction, which it describes as "very broad." 120 For example, retailers fall under this jurisdiction if they have a gross annual volume of business in interstate commerce of $\$ 500,000$ or more. ${ }^{121}$ Though the Ashurst-Sumners Act prohibits the sale of goods made by incarcerated workers in many channels of interstate commerce, its exception for sales to federal and state governments very likely brings employers selling goods pursuant to this exception under the statutory jurisdiction of the Board. Employers selling goods under the PIE program also very likely fall under the Board's statutory jurisdiction because these goods are allowed to enter the open market. These employers would only have to meet the Board's minimal sales volume threshold. Thus, the Board's requirements for asserting its statutory jurisdiction will not likely prohibit it from considering whether incarcerated workers are employees under the NLRA.

Even when the NLRB has the statutory authority to consider and decide an issue, it may properly decline to assert its jurisdiction over the issue when exercising jurisdiction would not effectuate the policies underlying the NLRA—promoting stability in labor relations. ${ }^{122}$ The Board's August 2015 decision in Northwestern University serves as a recent example of the

\footnotetext{
118 See 29 U.S.C. § 151.

${ }^{119}$ See Jurisdictional Standards, NATIONAL LABOR RELATIONS BOARD, https://www.nlrb.gov/rights-we-protect/jurisdictional-standards (last visited Jan. 28, 2017). ${ }^{120} I d$.

${ }^{121} \mathrm{Id}$.

${ }^{122}$ See N.L.R.B. v. Denver Bldg. Trades Council 341 U.S. 675, 684 (1951).
} 
Board declining to exercise its jurisdiction over a case, and it shows that the Board's reasons for declining to exercise its jurisdiction are not applicable to the situation of incarcerated workers.

In Northwestern University, the Board explains that asserting jurisdiction over a representation petition and determining whether Northwestern University football players who receive grant-in-aid scholarships are employees under the NLRA would not effectuate the policy underlying the Act. ${ }^{123}$ The Board emphasizes that this decision not to assert jurisdiction is based on its findings regarding the nature of sports leagues. ${ }^{124}$ Because of the control that leagues exercise over the individual teams within them and the fact that the "overwhelming majority" of teams in the leagues are public schools, over which the Board cannot exercise jurisdiction, the Board found that exercising its jurisdiction in this case would not promote stability in labor relations. ${ }^{125}$ In particular, the Board points to the "symbiotic relationship" among the various

${ }^{123}$ See Northwestern University, N.L.R.B. Case No. 13-RC-121359 at * 3 (2015). On January 31, 2017, the General Counsel of the NLRB sent a memorandum to the Board's regional directors stating that Division I Football Bowl Subdivision scholarship players in private universities are employees under the NLRA. Memorandum from Richard F. Griffin, Jr., General Counsel, to All Regional Directors, Officers-in-Charge, and Resident Officers 16 (Jan. 31, 2017). The General Counsel notes that the Board's decision in Northwestern University does not preclude this conclusion because the reasoning underlying the Board's decision not to assert jurisdiction over the players' representation petition is not relevant to the issue of whether the players are employees under the NLRA. See id. at 20. Thus, regardless of whether the Board certifies the players' petition to join a union, the players still have the right under the Act to engage in concerted activities for mutual aid or protection. See id. at 21-22. Though this memorandum does not carry the force of law, and though President Trump's General Counsel appointment may not continue the policies set forth in it, the memorandum is notable because it relies on the Board's reasoning in Boston Medical Center and Columbia University to find that the football players at issue in Northwestern University are employees under the NLRA. See id. at 18. Thus, it serves as support for the argument that the reasoning in Columbia University applies outside of the context of graduate teaching assistants. Further, it illustrates that even if the Board declined to assert its discretionary jurisdiction over incarcerated workers, these workers could still be employees protected by the Act based on the reasoning in Columbia University.

${ }^{124}$ See id.

${ }^{125} \mathrm{Id}$. Some have argued that the Board was incorrect in assuming that exercising jurisdiction would result in instability in this context and that the Board's stability rationale as a whole cuts too broadly. See Ben Levin, Guest Post: N.L.R.B. Missed Shot by Declining Jurisdiction in 
football teams, leagues, and the NCAA, which oversees them both, and argues that because of this relationship, labor issues involving an individual team would also affect the leagues and the NCAA, creating instability. ${ }^{126}$ The Board says of this context, "there is no 'product' without direct interaction among the players and cooperation among the various teams.”127

This is not the case in the context of incarcerated worker labor, however. The products of incarcerated worker labor exist without direct interaction between workers in one prison and workers in another and without direct interaction between public and private prison systems as a whole. Though it is true that many inmates work in public prisons over which the Board cannot exercise jurisdiction, the lack of direct interaction between these incarcerated workers and those in private prisons means that Board decisions regarding workers in private institutions will not create instability in the system as a whole. Further, as illustrated by the Board's exercise of jurisdiction in Columbia University, the fact that a type of labor exists in both a public and a private setting, as does graduate teaching assistant labor, cannot be the sole reason that the Board declines to exercise its jurisdiction. Given the coordinated and widespread strikes described in the introduction to this Note, it is also clear that the policies of the Act—alleviating industrial strife and unequal bargaining power between employers and employees—-would be furthered if the Board exercised jurisdiction over incarcerated workers. Though these distinctions between Northwestern University and the situation of incarcerated workers do not ensure that the Board

Northwestern Football Case for “Stability," ON LABOR (Aug. 20, 2015), https://onlabor.org/2015/08/20/guest-post-n-l-r-b-missed-shot-by-declining-jurisdiction-innorthwestern-football-case-for-stability/.

${ }^{126}$ See id.

${ }^{127} I d$. 
will exercise jurisdiction in a case involving these workers, they do show that the issue of exercising jurisdiction should not necessarily prevent incarcerated worker unionization.

\section{Employers in the Prison System}

A Board finding that incarcerated workers are employees under the NLRA would not grant protection to all prison labor organizations because not all incarcerated workers have employers that are covered by the Act. Some employers of incarcerated workers are not covered by the Act because it excludes federal and state governments from the employer category. As described in Part I, many incarcerated workers contribute to day-to-day prison operations in public institutions or work for government-owned corporations like UNICOR, over which the Board has no jurisdiction. ${ }^{128}$ Other employers are likely not covered by the Act because they do not meet the interstate commerce requirements for the Board's statutory jurisdiction. This is likely the case for the employment relationship between private institutions and incarcerated workers contributing to prison operations for them. However, approximately 130,000 inmates currently live in federal and state private prisons, and though the structures of the labor systems under which they work are not clear, some of these inmates manufacture goods for the private prison or local employers. ${ }^{129}$ A Board finding that these incarcerated workers are employees under, and thus protected by, the NLRA would move these workers one step further from the forms of modern-day slavery under which they currently work. The same could also be true for

\footnotetext{
${ }^{128}$ For an argument that government-owned prison industry corporations should not be excluded from NLRA coverage because they are proprietary enterprises indistinguishable from their private-sector counterparts, see Fink, supra note 14, at 967 n.102. ${ }^{129}$ See supra text accompanying notes 52-53.
} 
the unknown number of inmates who work for private corporations inside public prisons, like those at Perry Correctional Institute in South Carolina.

Because a Board finding that incarcerated workers are employees under the NLRA would primarily affect workers in private prisons, it is important to overcome the idea that these private prisons are not employers under the Act because they are "political subdivision[s]" of a state or federal government, a type of employer not covered by the Act. ${ }^{130}$ In N.L.R.B. v. National Gas Utility District of Hawkins County, Tennessee, the Supreme Court held that entities are political subdivisions of a state if they are "either (1) created directly by the state, so as to constitute departments or administrative arms of the government, or (2) administered by individuals who are responsible to public officials or to the general electorate." ${ }^{131}$ Private prison corporations are incorporated by private individuals rather than the state ${ }^{132}$ and their Boards are not elected or appointed by, and thus are not responsible to, public officials or the general electorate. Thus, these private prison corporations are not political subdivisions. A decision by the Supreme Court of Appeals of West Virginia lends additional support to this claim. In West Virginia ex rel. Youth Services Systems, Inc. v. Wilson, the court held that "a private corporation that enters into a contract with an agency of this State for the provision of juvenile detention services does not meet the definition of a 'political subdivision' under the [Governmental Tort Claims and Insurance Reform] Act.”133 Thus, the NLRA's exemption of political subdivisions from statutory coverage does not prohibit incarcerated worker unionization under the Act.

13029 U.S.C. § 152(2) (defining “employer” as “any person acting as an agent of an employer, directly or indirectly, but shall not include . . . any State or political subdivision thereof”). 131402 U.S. 600, 605 (1971).

132 See The CCA Story: Our Company History, CCA, http://www.cca.com/our-history (last visited Jan. 20, 2016) ("Back in 1983, three enterprising leaders came together . . . T. Don Hutto, Tom Beasley and Doctor Crants were each distinguished in their own right.”) 133515 S.E.2d 594, 599 (W. Va. 1999). The Governmental Tort Claims and Insurance Reform Act's definition of “political subdivision” comports with the Supreme Court's definition of the 


\section{State Statutes and NLRA Preemption}

As explained above, state private prisons and state public prisons that host private corporations that use incarcerated worker labor hold many of the workers who could receive protection under the NLRA. This situation implicates state laws that govern labor relations alongside the NLRA, some of which address the status of incarcerated workers as employees. For example, a Florida statute governing public-sector labor relations states that “"[p]ublic employee’ means any person employed by a public employer except: . . . . (f) Those persons who have been convicted of a crime and are inmates confined to institutions within the state."134 If the Board were to find that incarcerated workers are employees under the NLRA, many state legislatures will likely add similar language in state statutes governing private-sector labor relations in an attempt to limit the reach of the Board's finding. The ensuing conflict between state statutes and the Board's interpretation of the NLRA would require a determination of whether the NLRA preempts these state statutes.

A court evaluating whether the NLRA preempts state statutes that exclude incarcerated workers from the definition of "employee” could find that the Act preempts these statutes based on established precedent. In Weber v. Anheuser-Busch, Inc., the Supreme Court held that obvious, actual conflict between the Act and state statutes leads to "easy judicial exclusion of state action.” 135 If the Board found that incarcerated workers are employees under the Act, any state statutes excluding incarcerated workers from this definition would create obvious, actual

term. See id. at 597 (“The term 'political subdivision' is defined . . . as: any county commission, municipality and county board of education; any separate corporation or instrumentality established by one or more counties or municipalities, as permitted by law; any instrumentality supported in most part by municipalities; any public body charged by law with the performance of a government function and whose jurisdiction is coextensive with one or more counties, cities or towns ....")

${ }^{134}$ Florida Stat. Ann. § 447.203(3)(f) (2013).

135348 U.S. 468, 480 (1955). 
conflicts with the Act. As such, a court could easily find that the Act preempts such state statutes.

In order to further protect the primary jurisdiction of the Board to decide labor issues, the Supreme Court held in San Diego Building Trades Council Local 2620 v. Garmon that the NLRA preempts states from regulating conduct that is arguably protected by the Act. ${ }^{136}$ Under Garmon preemption, however, the NLRA does not preempt matters that are "deeply rooted in local feeling and responsibility.”137 Courts have applied this exception primarily to situations involving picketing, violence, or injury to the person. ${ }^{138}$ Even in instances like these, however, NLRA preemption can occur if the state regulation significantly affects NLRA rights or procedures. $^{139}$

Though the rule set out in Weber applies more directly to a Board finding that incarcerated workers are employees under the Act, a court could also look to Garmon to determine if such a finding preempts conflicting state laws. Given that such a finding would allow incarcerated workers to engage in conduct protected by the Act, a court considering preemption under Garmon could find that the Act preempts conflicting state laws, notwithstanding the exception for matters deeply rooted in local feeling. Further, though a state's general power over incarcerated people in its custody is arguably a matter deeply rooted in local feeling and responsibility, the specific issue of whether or not these people are employees under statutes governing labor relations is less so. This is especially true when contrasting this issue with those that typically fall under the exception-ones of violence and

136 See Stephen F. Befort, Demystifying Federal Labor and Employment Law Preemption, 13 LAB. L. 429, 431 (1998).

137359 U.S. 236, 244 (1959).

138 See Befort, supra note 136 at 432.

139 See id. (citing Sears, Roebuck \& Co. v. San Diego Dist. Council of Carpenters, 436 U.S. 180 (1978); Youngdahl v. Rainfair Inc., 355 U.S. 131 (1957)). 
injury—and when considering that state statutes excluding incarcerated workers from the definition of "employee" would ban conduct permitted by the NLRA. As such, a court considering NLRA preemption under either Weber or Garmon could find that the Act preempts such state statutes.

\section{E. Incarcerated Worker Labor Unions in Practice}

Obstacles to incarcerated worker unionization will exist even if the Board exercises its jurisdiction to find that these workers are employees under the Act and a court finds that the Act preempts any conflicting state statutes. Incarcerated worker unions will also face legal and practical obstacles as they begin to form and operate. The first of these obstacles arises in the Supreme Court's 1977 decision, Jones v. North Carolina Prisoners' Labor Union, Inc. There, an incarcerated worker labor union brought suit against the North Carolina Department of Correction, alleging that the Department violated the union's First and Fourteenth Amendment rights when it prohibited incarcerated workers from soliciting others to join the union, barred meetings of the union, and refused to deliver union publications mailed in bulk to the workers for distribution. ${ }^{140}$ In addressing these claims, the Court first noted that lawful incarceration brings about a necessary withdrawal or limitation of privileges and rights, including the First and Fourteenth Amendment rights at issue in the case. ${ }^{141}$ To determine the degree to which incarceration can limit these privileges and rights, the Court balanced the institutional needs and objectives of prisons against the rights established in the Constitution. ${ }^{142}$ The Court also granted wide-ranging deference to the decisions of prison administrators regarding institutional objectives. ${ }^{143}$ In light of this deference, the Court in Jones found that the Department's

140 See Jones v. N.C. Prisoners’ Labor Union, Inc., 433 U.S. 119, 121 (1977).

141 See id. at 125.

142 See id. at 129.

143 See id. at 126, 128. 
“reasonable considerations of penal management” did not "trench untowardly" on the inmates' constitutional rights, ${ }^{144}$ and thus its restrictions on the union activity could stand.

The North Carolina Department of Correction's restrictions would certainly constitute violations of the NLRA. Yet, given the outcome of Jones, prisons would likely put similar restrictions in place if incarcerated worker unions began to form after a Board decision finding that these workers are employees under the Act. Challenges to these restrictions would then present courts with the task of reconciling Jones with the Board's finding. Courts could approach this task and find in favor of incarcerated worker union activity in at least two ways.

First, a case regarding employer restrictions on incarcerated worker organizing would present a court with an opportunity to overrule Jones. Many have argued that a court should do just this. In an article on the future of incarcerated worker unions after the Court's decision in Jones, Regina Montoya and Paul Coggins argue that:

The [C]ourt offered three rationales for its decisions in Jones. First, the Court took the position that the judiciary should play a very limited role in prison litigation, and that courts should accord "wideranging deference to ... the decisions of prison administrators. Second, the Court expressed the view that adequate alternatives for prisoners' unions existed. Third, the Court accepted the prison authorities' assertion that "the concept of a prisoners' labor union was itself fraught with potential dangers" to order and security. Each of the three rationales underlying the Jones decision is erroneous. ${ }^{145}$

Though the Court's rationales in Jones may be erroneous, it is possible that a court would not overturn its reasoning, which is based in First and Fourteenth Amendment principles, in a case arising under the NLRA.

\footnotetext{
144 See id. at 131-32.

145 Regina Montoya \& Paul Coggins, The Future of Prisoners' Unions: Jones v. North Carolina Prisoners' Labor Union, 13 HARV. C.R.-C.L. L. REV. 799, 801-02 (1978) (citations omitted).
} 
However, a court deciding a case regarding employer restrictions on incarcerated worker organizing after a Board finding that these workers are employees under the Act could take a second approach to prohibiting employer restrictions. A court confronting such a case could distinguish Jones because its holding is based in the First and Fourteenth Amendments rather than the NLRA and could then decline to follow the reasoning in Jones in a case arising under the NLRA. Such a decision would allow the court to avoid overturning precedent but would also allow it to avoid the arguably flawed reasoning in Jones. It would also allow the court to acknowledge and effectuate the NLRA's purpose—alleviating industrial strife and unequal bargaining power between employers and employees—a purpose that is not at issue under, and thus is not properly addressed by reasoning based in, First and Fourteenth Amendment principles. In cases arising under the NLRA, the NLRB and courts could instead follow established Board law regarding employer restrictions on NLRA rights, which would be less restrictive of incarcerated worker unionization than the Court's holding in Jones.

Thus far, Part III of this Note has addressed and offered solutions to a number of legal obstacles to incarcerated worker unionization. The remainder of this Part seeks to overcome a practical obstacle-envisioning and supporting incarcerated worker labor unions as they form. Though incarcerated worker labor unions may seem like unlikely or untenable organizations, they are not without precedent. ${ }^{146}$ Between 1971 and 1975, unions formed in prisons in 13 states, and these unions had more than 11,000 members combined. ${ }^{147}$ In nearly every prison where there was a union, more than $90 \%$ of the incarcerated population wanted affiliation. ${ }^{148}$

\footnotetext{
${ }^{146}$ For detailed accounts of unions in U.S. prisons in the 1970s, see DONALD F. TIBBS, FROM Black Power to Prison Power: The Making of Jones V. North Carolina Prisoners' LABOR UnION 155-56 (2002); C. Ronald Huff, Unionization Behind the Walls, 12 CRIMINOLOGY 175, 183-86 (1974).

${ }^{147}$ TIBBS, supra note 146, at 155.

${ }^{148} \mathrm{Id}$. at 156.
} 
The structure and demands of these unions varied from prison to prison. In 1971, inmates at Green Haven Correctional Facility, outside Manhattan, organized the Prisoners' Labor Union at Green Haven with the assistance of New York Legal Aid Society’s Prisoners’ Rights Project. ${ }^{149}$ The union notified the superintendent of Green Haven that it wanted to be recognized as the exclusive bargaining agent for the inmates and requested a meeting for negotiations on wages, hours, and working conditions. ${ }^{150}$ The Ohio Prisoners' Labor Union also formed in 1971 and set as its goals minimum-wage salaries and workmen's compensation for incarcerated workers, correcting dangerous working conditions, and encouraging private industry to come into the institutions, among other things. ${ }^{151}$ Though the Supreme Court's 1977 decision in Jones undercut the growing prisoners' union movement in the United States, ${ }^{152}$ incarcerated worker unions currently operate in other countries. In Argentina, the Sindicato Único de Trabajadores Privados de la Libertad Ambulatoria (“SUTPLA"), a union formed in 2012 of people incarcerated in a Buenos Aires prison, has 800 members and is recognized under an agreement with the Federal Penitentiary Service. ${ }^{153}$ Leaders of the Argentinean trade union federation to which SUTPLA belongs say that the International Labor Organization is closely watching SUTPLA because it may serve as an example for other countries to follow. ${ }^{154}$ In addition to examples from past and present incarcerated worker unions, visions for the widespread operation of these unions in the United States also come from scholars. In her article

\footnotetext{
${ }^{149} \mathrm{Id}$. at 155.

${ }^{150}$ Emanuel Perlmutter, Prisoners' Union Formed Upstate, N.Y. TIMES, Feb. 8, 1972, at 1.

151 See Huff, supra note 146, at 178-83.

152 See Susan Blankenship, Revisiting the Democratic Promise of Prisoners' Labor Unions, in 37 StUdies In LAW, Politics, AND SociETy 241, 244 (Austin Sarat ed., 2005).

153 See Marcela Valente, First Prisoners' Trade Union Defends Rights in Argentina, INTER PrESS SERVICE, June 7, 2013, http://www.ipsnews.net/2013/06/first-prisoners-trade-union-defendsrights-in-argentina/.

${ }^{154}$ Id.
} 
on the feasibility of incarcerated worker labor unions, Susan Blankenship suggests that these unions' constitutions could provide for elected leaders who frequently rotate out of their positions in order to provide ample leadership opportunities for those who want them and to reduce the potential for envy or resentment of inmates in these positions. ${ }^{155}$ Blankenship also envisions a non-adversarial, interest-based collective bargaining context in which the parties would come to the bargaining table with proposals for reaching their shared goals. ${ }^{156}$ Scholars also acknowledge that the unique context of incarceration may call for some limitations on the unions that form within it. In his analysis of proposals for incarcerated worker labor unions, Paul R. Comeau notes that as in the case of public employees, incarcerated workers might be denied the right to strike, an outcome that institutions could justify with considerations of safety and order both within and outside the institution. ${ }^{157}$ Comeau also suggests that institutions could limit the size of the audience to a union gathering or the location or time of such a gathering. ${ }^{158}$ Further, though incarcerated worker unions could call attention to and seek to address prison conditions generally, the NLRA would only require employers to bargain with unions over wages, hours, and working conditions.

In addition to envisioning how incarcerated worker unions could operate, scholars, as well as courts, ${ }^{159}$ have acknowledged the potential benefits of these unions. In an article on the

\footnotetext{
155 See Blankenship, supra note 152, at 250.

156 See id. at 251.

${ }^{157}$ See Paul R. Comeau, Labor Unions for Prison Inmates: An Analysis for a Recent Proposal for the Organization of Prison Labor, 21 Buffalo L. REV. 963, 973 (1971).

${ }^{158}$ Id. at 973-74.

159 See Goodwin v. Oswald, 462 F.2d 1237, 1245-46 (2d. Cir. 1972) (Oakes, J., concurring) ("Promoting or at least permitting the formation of a representative agency might well be, in the light of past experience, the wisest course for correctional officials to follow.”); cf. Landman v. Peyton, 370 F.2d 135, 141 (4th Cir. 1966) (noting that "[e]xperience teaches that nothing so provokes trouble for the management of a penal institution as a hopeless feeling among inmates that they are without opportunity to voice grievances or to obtain redress for abusive or oppressive treatment”).
} 
causes of and ways to avoid prison riots, Vernon Fox argues that "[s]ome type of inmate selfgovernment that involves honest and well supervised elections of inmate representatives to discuss problems, make recommendations, and perhaps, even take some responsibilities from the administration could be helpful." ${ }^{160}$ In an article on the need for restructuring of the prison economic system, Sarah M. Singleton notes that incarcerated workers receiving equitable payment for work performed could be able to provide support for their family, continue payments on social security, provide restitution if applicable to their case, and save money to assist themselves upon their release from prison. ${ }^{161}$ Similarly, Comeau notes that incarcerated worker unions that offer power to inmates and that are designed to eliminate abuses in prisons could be useful tools for the "genuine rehabilitation" of incarcerated individuals. ${ }^{162}$ Indeed, Comeau argues:

In the general labor force, employer acceptance of and cooperation with labor organization has resulted in a reduction of union militancy and the stabilization of industrial relations. If the formation of unions within correctional facilities would have this effect, it is possible that administrators would have legal and social responsibility to allow unionization. ${ }^{163}$

\section{Conclusion}

In an article on the intersection between law and prisons, Jonathan A. Willens writes:

The decision in Jones ... presented the substance of imprisonment, what the prison will be, and the Court refused to look. ... [E]ven while refusing to look at the substance of imprisonment, the Court

\footnotetext{
${ }^{160}$ Vernon Fox, Ph.D., Why Prisoners Riot, 35 Fed. Probation 9, 13 (1971).

${ }^{161}$ Sarah M. Singleton, Unionizing America's Prisons-Arbitration and State-Use, 48 IND. L. J. 493, 501 (1972).

162 See Comeau, supra note 157, at 982-83. Comeau's use of the term "genuine rehabilitation" works alongside the arguments of others who push back against the use of the term "rehabilitation" to describe what actually occurs in prisons. See Frank Browning, Organizing Behind Bars, RAmparTs, Feb. 1972, at 43 (“Or, as San Francisco Prisoners Union President Willie Holder puts it, rehabilitation is really only being reconstructed to accept prison life and authority.”).

163 Comeau, supra note 157, at 972.
} 
legitimates a particular substance by imposing and enforcing its legal structure. Because this legal structure rests on a particular conception of what prison is, the law creates a prison that increasingly reflects this conception. ${ }^{164}$

In this way, courts and the law build prisons. In this way too, the Board, courts, and the public currently have an opportunity to reshape the prisons that they have built. The Board's decision in Columbia University creates an opening for finding that incarcerated workers are employees under the NLRA and are thus able to form unions protected by the Act. Though a number of obstacles will likely arise on the path to incarcerated worker unionization, this Note offers solutions to these obstacles and argues that given the ways in which prison labor is a form of modern-day slavery, the Board and courts should take up these solutions.

164 Jonathan A. Willens, Structure, Content and the Exigencies of War: American Prison Law After Twenty-Five Years 1962-1987, 37 AM. U. L. REV. 41, 113 (1987). 